\title{
Cover crop and mulch practices reduce agricultural pollutant loads in stormwater runoff from plastic tunnels
}

\author{
Results from a trial with two raspberry growers in coastal California suggest that using a barley \\ cover crop or mulch can reduce potential groundwater pollutants in soil and leachate.
}

by Oleg Daugovish, Ben Faber, Eta Takele, Jamie Whiteford and Laosheng Wu

\section{Abstract}

Macrotunnel production systems contribute over $\$ 1$ billion to California's economy, but despite increased use, guidance to help macrotunnel growers limit agricultural pollutant loads in rainfall-induced runoff is sparse. Using raspberry as a model crop, we evaluated four runoff management practices during two rainy seasons of the normal 3-year raspberry production cycle: barley cover crop seeded at 500 pounds per acre, weed barrier fabric, yard waste mulch spread 2 to 3 inches thick, and polyacrylamide (PAM). Treatments were applied to 300-foot-by-6-footwide post rows. Barley cover crop and mulch reduced combined nitrate and nitrite nitrogen in runoff by $21 \%$ to $48 \%$ at some runoff events and reduced nitrate nitrogen in soil and leachate to groundwater by $52 \%$ to $90 \%$. All treatments reduced turbidity and phosphorus levels in runoff and had 75\% to $97 \%$ less sediment accumulation compared with bare soil. Additionally, all treatments except PAM reduced weed densities by $48 \%$ to $87 \%$ compared with bare ground, which reduced the costs of weed management. Barley cover crop had the lowest estimated costs $(\sim 60.00$ per tunnel period), while PAM and mulch were highest ( $\sim 193.00$ per tunnel period).

Online: https://doi.org/10.3733/ca.2020a0004
$\mathrm{M}$ acrotunnel production has been increasing in coastal counties of California and is poised for expansion due to its recent adoption as a standard practice by the U.S. Department of Agriculture (USDA NRCS 2019). In high tunnel production, crops are grown within plastic-covered structures to enhance crop performance, extend production seasons and to protect crop quality. While most caneberries, some strawberries, cut flowers, herbs and leafy greens are widely grown under plastic in California, contributing \$1 billion to the state's economy, in other states small fruits, melons and nuts are also grown in high tunnel systems. This interest in plasticulture tunnels is driven by many factors: increased production due to season expansion; reduced exposure to deleterious weather events; consumer demand for fresh, local produce; and national interest in reducing transportation-related greenhouse gas emissions, amongst other concerns. Unfortunately, it comes at a time when climate-induced weather pattern changes, particularly shorter-duration, higher-frequency storm events, are expected to become the norm (Westra et al. 2014).

The plastic covering hoop structures can reduce the available permeable surface of a field's production area by over $90 \%$, which increases the volume of
In coastal California, most caneberries, some strawberries, cut flowers, herbs and leafy greens are grown in plastic-covered structures like the ones shown here.
16

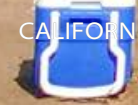


water likely to run off a field in a storm event (RCDMC 2014). During rains, water intercepted by plastic covers is channeled into post rows (furrows with tunnel-supporting posts), accelerating soil erosion, especially on slopes, which ultimately degrades surface water quality. In California, surface water quality is regulated by the State Water Resources Control Board through the Irrigated Lands Regulatory Program (ILRP 2017). To protect water quality, California regional water quality control boards have adopted different measures to regulate pollutants in water from agricultural operations, including implementation of best management practices (BMPs) (Lu et al. 2008). Typical pollutants in areas with exceedances of total maximum daily loads (TMDLs) include nitrogen, sediment, phosphorus and pesticides, such as chlorpyrifos. Many surface water TMDL exceedances occur during the rainy season, indicating the need for practices that address stormwater runoff. In some areas, management practices that reduce rain-induced leaching of soluble pollutants into groundwater may also be needed.

\section{Stormwater management treatments}

In this project we compared treatment efficacies and costs of untreated tunnel post rows with rows treated under four different practices in plastic-covered raspberry operations at Somis (Ventura County) and Santa Maria (Santa Barbara County), California. Both sites were on moderate slopes ( $2 \%$ to $10 \%$ ), but the beds were planted on the contour to reduce runoff and were on a $1 \%$ slope at both sites. The post row treatments were selected based on previous work (M. Cahn, personal communication) and potential feasibility for caneberry operations.

Each treatment was applied to 6-foot-by-300-foot post rows (each row is an 1,800-square foot plot) in an experiment with randomized complete block design with three replications at both sites. Site conditions are described in table 1 . The project focused on the rainy seasons of 2016-2017 and 2017-2018.

The four treatments were as follows:

A barley cover crop ('U.C. 476') was seeded in 2016 (July at Somis and November at Santa Maria) at 500 pounds per acre with a seed spreader, lightly raked into the soil and established with sprinkler irrigation used for delivering overhead water to newly planted raspberry roots (a standard propagation approach). At both locations we reseeded barley at the same rate during the second rainy period of the project (January 2017) to increase cover crop density in areas lacking ground cover.

Weed block fabric (DayBlack/Premium Weedmat, Dewitt) is commonly used in organic and hydroponic production systems. Fabric was unrolled and pinned by hand to cover the post-row surface between raspberry beds prior to post installation. The fabric remained in place during the experiment and was unpinned and rolled up at the end of the project for potential reuse.

Yard waste mulch from local suppliers (Agromin for Somis and Santa Barbara County Public Works Green Waste for Santa Maria) was delivered to the project sites. Mulch was a woody $<2$-inch screened material with $<20 \%$ fine components. Different mulch sources at the two sites were used because the distance between sites and volume requirements for each site were prohibitively large to source from a single supplier. Mulch was delivered by tractor to post rows, where it was spread with rakes to cover the entire post row with a 2- to 3-inch thick layer. At both locations mulch was applied once prior to post installation and persisted throughout the trial period.

Polyacrylamide (PAM; Soil Binder DC, J.R. Simplot Company), a nontoxic soil-binding polymer, was applied prior to rain events (or as needed based on efficacy) at a rate of 2 pounds per acre. In 2016-2017, PAM was mixed with water and applied with a backpack sprayer, but due to plugging of nozzles we dispersed dry PAM to post rows instead in 2017-2018 and observed similar efficacy and increased ease of application.

\section{Runoff and soil collection, data analyses}

In the 2016-2017 season, we collected runoff samples by hand (grab samples) within $30 \mathrm{~min}$ from the beginning of the runoff generation, approximately 25 feet away from the ends of each of the treatment post rows (to prevent potential runoff mixing from adjacent post rows). About 250 milliliters of runoff water in each sample were brought from field sites to the UC Cooperative Extension (UCCE) Ventura County lab and immediately tested for turbidity using a turbidimeter (Model 2100P, Hach Company, Loveland, Colo.), acidified with sulfuric acid to reach $\mathrm{pH} 3$ and either shipped immediately to the ANR analytical lab at UC Riverside or stored at $4^{\circ} \mathrm{C}$ until shipment. Levels of nitrogen forms (nitrate $\left[\mathrm{NO}_{3}\right]$, nitrite $\left[\mathrm{NO}_{2}\right]$ and ammonium $\left.\left[\mathrm{NH}_{4}\right]\right)$ and total nitrogren and phosphorus were determined using a

TABLE 1. Site characteristics in raspberry tunnel runoff management project

\begin{tabular}{|c|c|c|c|c|c|c|c|}
\hline $\begin{array}{l}\text { Experimental } \\
\text { site }\end{array}$ & Soil type & $\begin{array}{l}\text { Organic } \\
\text { matter }\end{array}$ & $\mathrm{pH}$ & $\begin{array}{c}\text { Slope, } \\
\%\end{array}$ & $\begin{array}{c}\text { Rainfall, total in } \\
\text { inches, 2016-2017 }\end{array}$ & $\begin{array}{c}\text { Rainfall, total in } \\
\text { inches, 2017-2018 }\end{array}$ & Plastic cover on tunnels \\
\hline Somis & Mocho loam & 1.8 & 7.8 & 5 & 16.63 & 6.74 & Duration of the project \\
\hline Santa Maria & Oceano sand & 2.3 & 6.1 & 9 & 18.84 & 6.48 & Feb-May each year \\
\hline
\end{tabular}
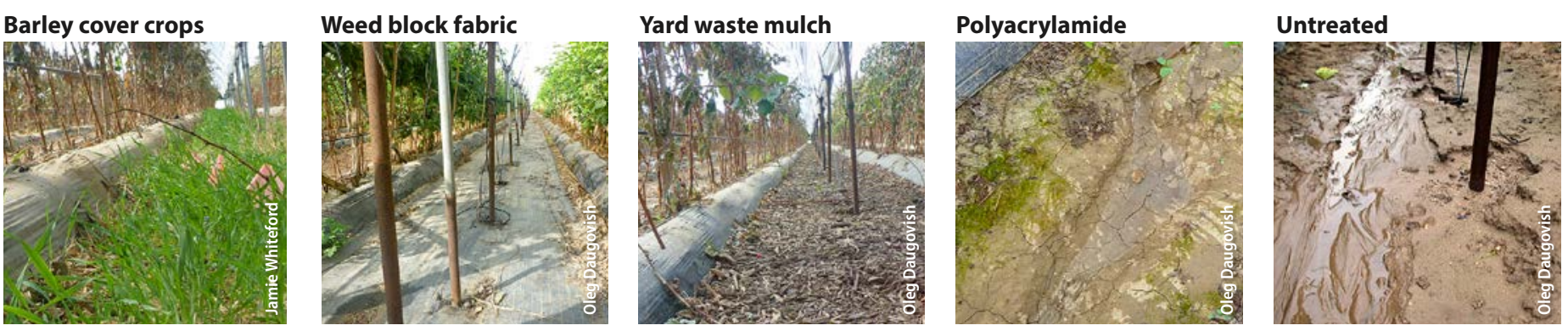

Treatments applied to raspberry tunnel post rows at Somis and Santa Maria. 
Discrete Analyzer AQ2 (Seal Analytical Inc., Mequon, Wis.).

In 2017-2018, we collected grab samples as described above. We also collected runoff in 5-gallon buckets installed at 25 feet from the end of post rows (passive samplers) to intercept first flush of runoff at soil surface level. Additionally, we installed suction lysimeters (AGQ Labs, Oxnard, Calif.) about 30 feet away from the ends of the post rows at 8-inch depth at Santa Maria and 8- and 24-inch depths at Somis and collected leachate (water that has percolated through soil) after rains.

In 2017-2018 we also collected sediment from the buckets after runoff occurred, and the sediment samples were dried and weighed at the UCCE Ventura County lab. In April 2018, we took soil samples (15 cores per plot at 0 - to 6-inch and 6- to 12 -inch depths) that were analyzed for soil moisture, nitrate nitrogen $\left(\mathrm{NO}_{3}-\mathrm{N}\right)$ and phosphorus content.

\section{Weed densities and raspberry shoots}

Weed numbers were determined by counting all germinated weeds in each 1,800-square foot plot at each site on three dates. Predominant weed species at

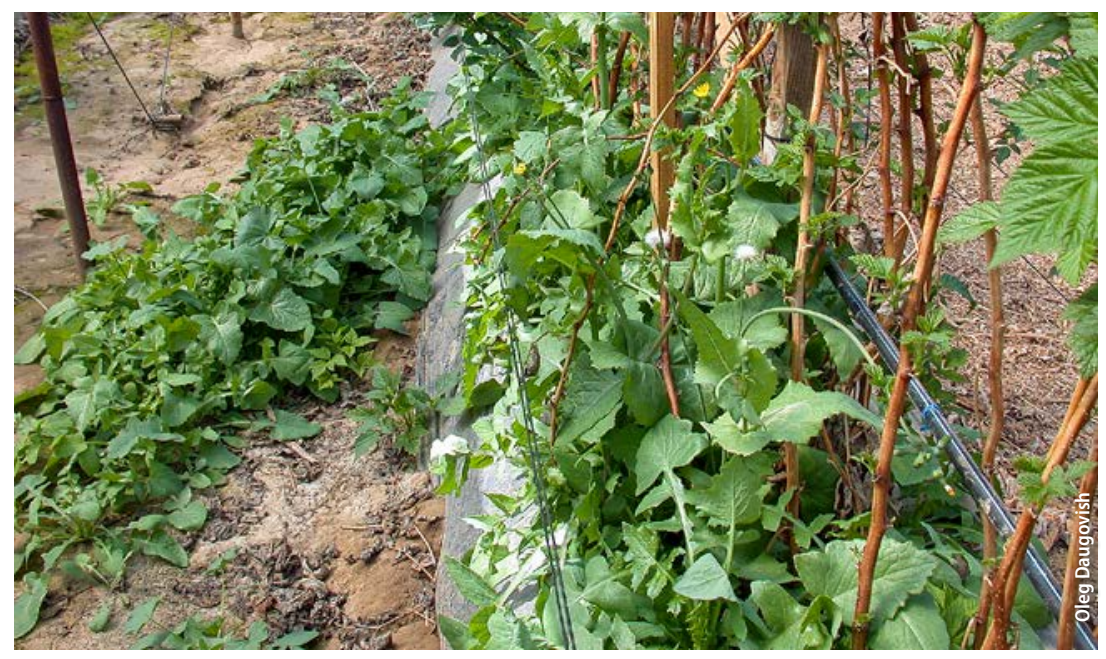

Bare ground allows erosion and weeds, which then move into crop beds.

TABLE 2. Soil moisture and nitrate nitrogen in 0 - to 12-inch soil profile three days after rain (3.25 inches) under raspberry post row treatments, March 29, 2018

\begin{tabular}{|l|c|c|c|c|}
\hline & \multicolumn{3}{|c|}{ Somis } & \multicolumn{2}{c|}{ Santa Maria } \\
\hline Treatments & Moisture & Nitrate nitrogen & Moisture & Nitrate nitrogen \\
\hline & $\%$ & $p p m$ & $\%$ & $p p m$ \\
\hline Untreated & $18.5 \mathrm{~b}$ & $28 \mathrm{a}$ & $8.7 \mathrm{ab}$ & $11.2 \mathrm{a}$ \\
\hline Fabric & $18.4 \mathrm{~b}$ & $22 \mathrm{a}$ & $7.6 \mathrm{~b}$ & $2.3 \mathrm{~b}$ \\
\hline Mulch & $20.8 \mathrm{a}$ & $7.8 \mathrm{~b}$ & $8.9 \mathrm{a}$ & $9.8 \mathrm{ab}$ \\
\hline Barley & $19.6 \mathrm{ab}$ & $4.4 \mathrm{~b}$ & $8.7 \mathrm{ab}$ & $4.7 \mathrm{~b}$ \\
\hline PAM & $18.3 \mathrm{~b}$ & $35 \mathrm{a}$ & $8.4 \mathrm{ab}$ & $8.4 \mathrm{~b}$ \\
\hline
\end{tabular}

Treatment means with the same letter in each column are not significantly different at $P=0.05$.
Somis were little mallow (Malva parviflora) and annual sowthistle (Sonchus oleraceus), and horseweed (Conyza canadensis) and annual bluegrass (Poa annua) at Santa Maria. Additionally, in April 2018 at Somis we counted the numbers of volunteer raspberry shoots (suckers) in all plots.

Runoff, weed and cane data were analyzed using the GLM Procedure in SAS (SAS version 9.0, SAS Institute, Cary, N.C.) with the overall error rate controlled by Tukey-Kramer adjustment.

\section{Economic analyses}

We calculated the costs of each treatment for the 1,800square foot experiment plot and then extrapolated the costs into a per acre basis for one tunnel use period. A tunnel use period covers a 3-year production cycle of raspberry from establishment until termination. Costs of treatments included materials, labor and equipment when applicable. Granular dry PAM formulation application to soil was used in the analyses. We also adjusted the treatment's costs if it provided weed control benefit. In addition, some treatments can serve for more than one tunnel use period. Therefore, we distributed the costs accordingly.

\section{Treatment effects on runoff and water retention}

Not all treatments had runoff during light rains. Barley cover crop and yard waste mulch likely interfered with low flows and aided water retention in post rows. We observed slower flows and greater puddling in post rows with barley or mulch than in other treatments or untreated soil (data not shown). Soil sampled 3 days after rain in March 2018 at Somis had 8\% to 12\% (w/w) greater moisture content at both sampling depths under mulch compared with other treatments (table 2). Mulch also conserved more soil moisture than fabric at Santa Maria (table 2).

\section{Nitrogen in runoff}

Combined nitrite and nitrate (NOx) levels in runoff samples ranged from 0.29 to 6.48 milligrams per liter $(\mathrm{mg} / \mathrm{L})$ over two seasons of sampling. This variability is due to the intensity and frequency of the rains during this period, which also affected the accumulated fertigated nitrogen that occurred between rain events.

Fabric and PAM did not reduce nitrate or nitrite in runoff compared with untreated soil at any of the sampling dates at both locations and sampling seasons (data not shown), while mulch was equally ineffective in 2016-2017 in reducing NOx in runoff at both locations. During one out of five runoff events in 2016-2017, barley reduced NOx levels in runoff by $48 \%(P=0.023)$ compared with untreated soil, but not significantly during other rain events of that season (data not shown).

During two out of five runoff events (March 10, 2018 and March 13, 2018) at Somis in 2017-2018, barley 
reduced NOx levels in runoff by $71 \%$ and $82 \%(P<0.05)$ and mulch reduced them by $67 \%$ and $91 \%(P<0.1)$ compared with untreated soil, but reductions were not significant at other sampling events. At Santa Maria, none of the treatments had significant impact on NOx in runoff when compared with untreated soil $(P>0.1)$ (data not shown).

All treatments at Somis were effective in reducing ammonium in runoff in 2016-2017 compared with untreated soil (table 3), but only barley was effective in 2017-2018. The overall greater average levels of ammonium in 2017-2018 were likely due to use of passive samplers that intercepted the first flush of runoff, which may have had a greater concentration of pollutants than runoff collected later (such as with grab samples in 2016-2017). Ammonium is typically carried on sediments, so lower ammonium would indicate less sediment movement.

This suggests that barley cover crop and yard waste mulch can reduce both the concentration of dissolved ammonium nitrogen in runoff and the volume of runoff, leading to potential reductions in nitrogen losses to the environment compared with untreated soil.

\section{Nitrate nitrogen in soil and leachate}

Soil under barley and mulch had significantly less nitrate nitrogen compared with other treatments in March 2018 at Somis (table 2). At Santa Maria, all treatments except for mulch had $25 \%$ to $81 \%$ less nitrate nitrogen than that of untreated soil, although mulch was also similar to all other treatments. Mulch deterioration might have reduced its efficacy at Santa Maria.

At Santa Maria, nitrate nitrogen levels in leachate collected at 8-inch depth on all sampling dates ranged from 12 to 27 parts per million (ppm) in PAM and untreated plots, which was $52 \%$ to $80 \%$ greater $(P<0.05)$ than those in other treatments (data not shown). At Somis a similar trend was observed: nitrate nitrogen levels in leachate under PAM and untreated soil were 7 to $22 \mathrm{ppm}$, which was $80 \%$ to $90 \%$ greater $(P<0.01)$ than those under barley or mulch. Leachate nitrate concentrations under fabric were not different $(P=0.8)$ from those in untreated soil (data not shown).

These results suggest that barley and mulch can reduce nitrate nitrogen in soil and leachate. Mulch and cover crop (including straw and stubble) act as a barrier to runoff water with dissolved nitrogen and sediment and may retain nitrogen to be used for cover crop growth and for residue and mulch decomposition.

\section{Turbidity, sediment and phosphorus in runoff}

Turbidity (a measure of suspended sediment loads) in first flush of runoff was reduced 5- to 10 -fold by all treatments compared with untreated soil at both locations in 2018 (figs. 1 and 2). These results were similar to turbidity in grab samples taken in 2017 and 2018 (data not shown), which suggests that all treatments were effective in reducing waterborne sediments on site.
Additionally, $75 \%$ to 97\% less sediment was collected from passive samplers in all treated post rows compared with those in untreated soil, as shown for March 10, 2018 (fig. 3). Relatively high sediment load in fabric treatment resulted from deposits of soil on top of the fabric during removal of plastic from raspberry beds. Similar to the
TABLE 3. Average ammonium concentrations of five runoff events (grab samples in 2016-2017) and passive samples (2017-2018) at Somis

\begin{tabular}{|l|c|c|}
\hline \multirow{2}{*}{ Treatments } & \multicolumn{2}{|c|}{ Ammonium $\mathrm{mg} / \mathrm{L}$} \\
\cline { 2 - 3 } & $2016-2017$ & $\mathbf{2 0 1 7 - 2 0 1 8}$ \\
\hline Barley & $0.04 \mathrm{~b}$ & $0.47 \mathrm{~b}$ \\
\hline Fabric & $0.04 \mathrm{~b}$ & $3.59 \mathrm{ab}$ \\
\hline Mulch & $0.06 \mathrm{~b}$ & $0.57 \mathrm{ab}$ \\
\hline PAM & $0.05 \mathrm{~b}$ & $1.30 \mathrm{ab}$ \\
\hline Untreated & $0.24 \mathrm{a}$ & $5.94 \mathrm{a}$ \\
\hline
\end{tabular}

Treatment means with the same letter in each column are not significantly different at $P=0.1$.

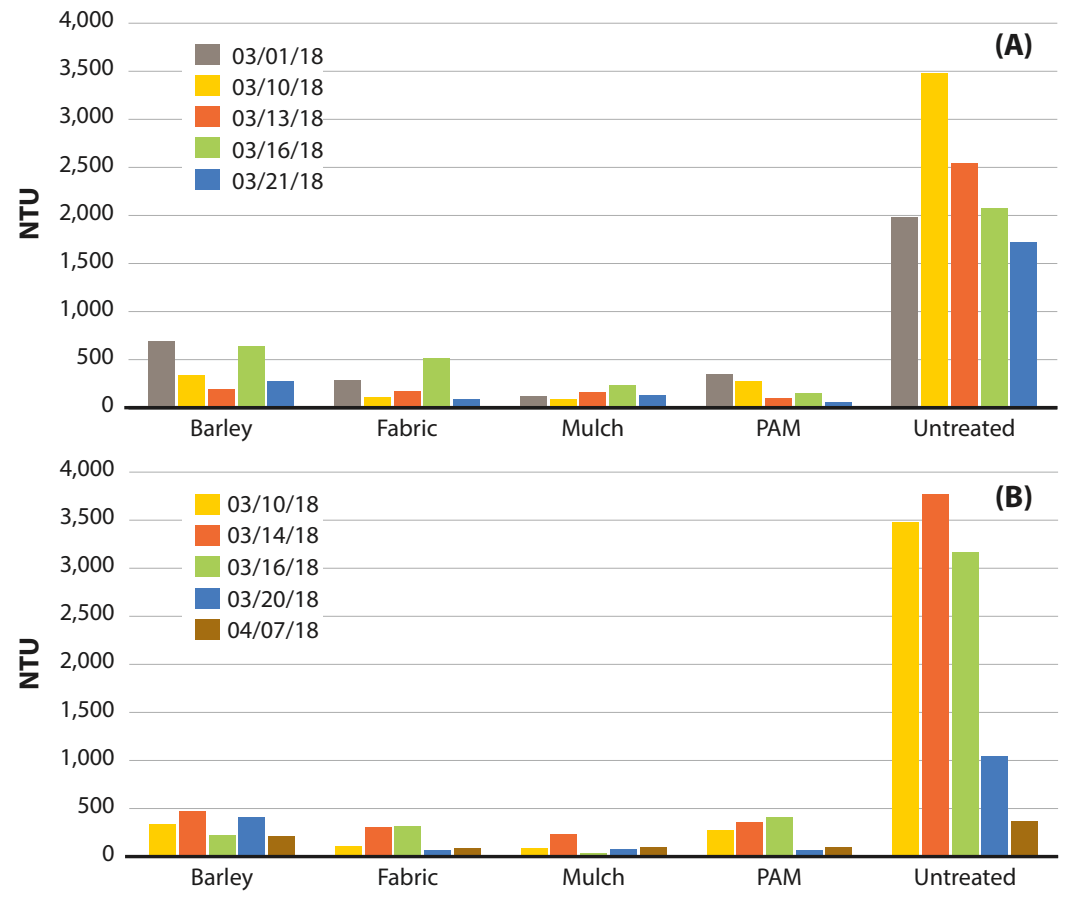

FIG. 1. Turbidity (in Nephelometric Turbidity Units, NTU) in first flush of runoff in 2018 at Somis (A) and Santa Maria (B). Untreated $>$ rest (at $P=0.05$ ) at all dates.

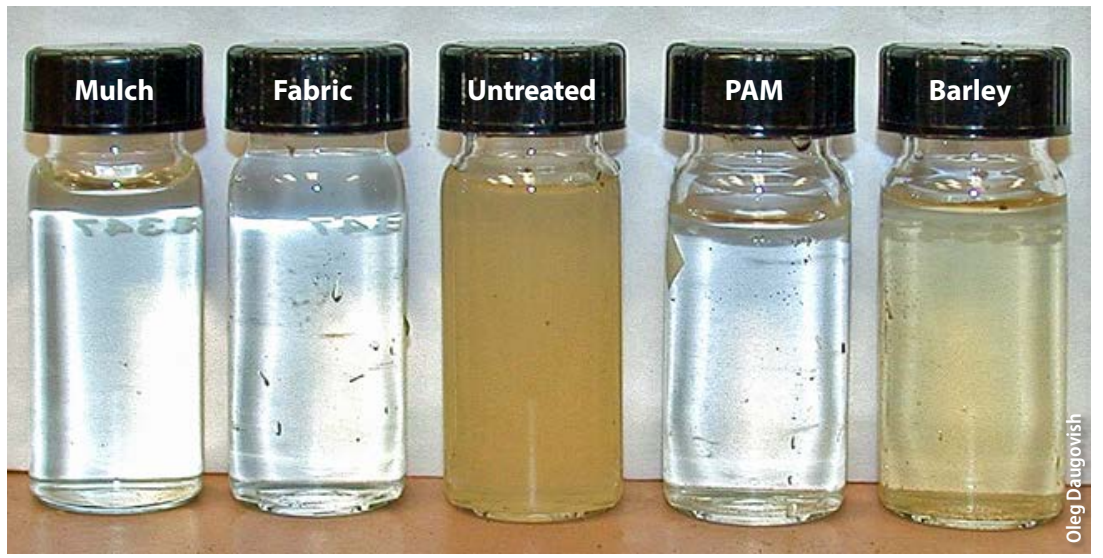

FIG. 2. Turbidity of runoff water in first flush of runoff from raspberry post rows with different treatments and untreated bare soil at Somis on March 10, 2018. 
March 10 rain event, we observed significantly lower sediment levels after other rains in all treated post rows compared with untreated rows (data not shown). We also observed fewer erosion channels in treated post rows compared with untreated plots at both sites during the trial.

Besides the agronomic benefits, retaining soil in the field is also a good pesticide management practice because soil-adsorbed pesticides will stay in the field and

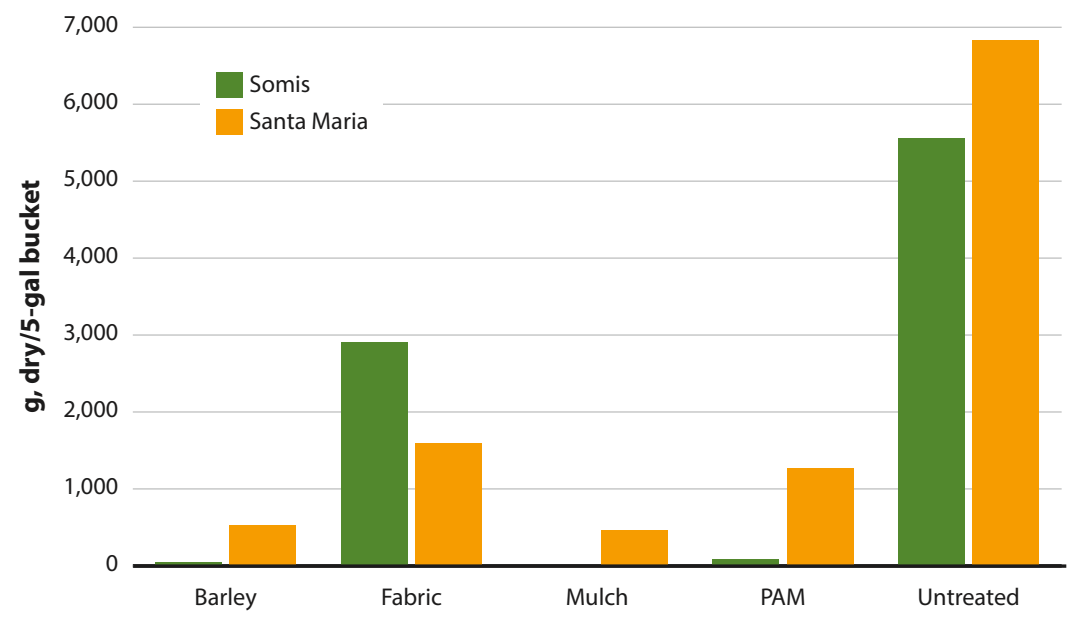

FIG. 3. Sediment collected after 3.25 inches of rain on March 10, 2018, in passive samplers in treated and untreated raspberry post rows. Untreated $>$ rest (at $P=0.05$ ).

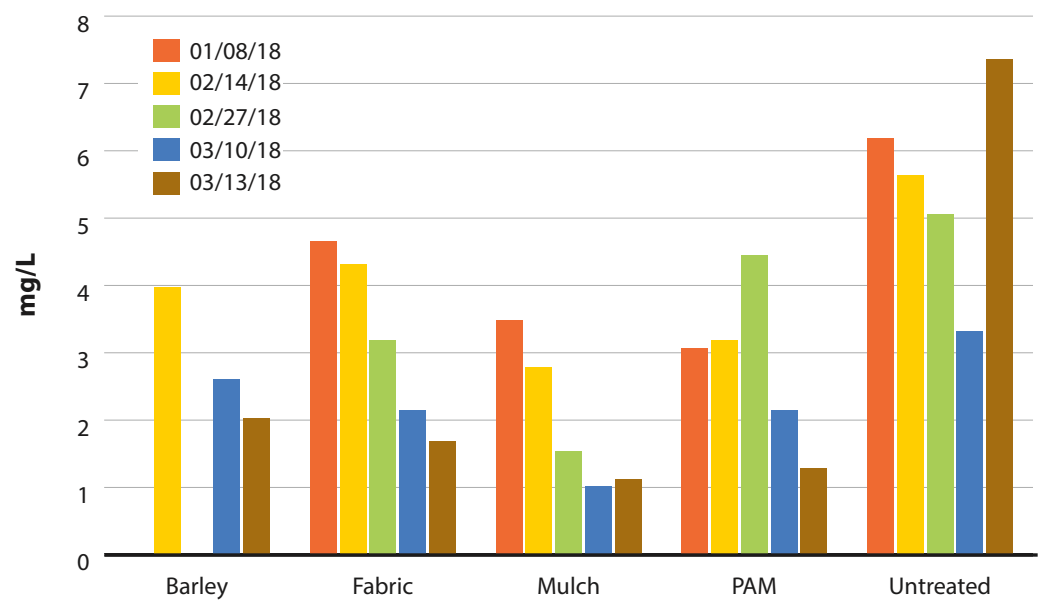

FIG. 4. Total phosphorus in first flush of runoff in 2018 at Somis. Untreated $>$ the rest $(P=$ 0.05 ), except PAM on 02/27/2018 (similar to untreated, $P=0.23$ ).

TABLE 4. Weed densities in post rows (plants per 1,800 $\mathrm{ft}^{2}$-post row) at Somis and Santa Maria

\begin{tabular}{|l|c|c|c|c|c|c|}
\hline & \multicolumn{4}{|c|}{ Somis } \\
\hline Treatments & $11 / 23 / 2016$ & $02 / 15 / 2017$ & $01 / 17 / 2018$ & \multicolumn{3}{c|}{ Santa Maria } \\
\hline Untreated & $206 \mathrm{a}$ & $651 \mathrm{a}$ & $625 \mathrm{a}$ & $7 \mathrm{a}$ & $76 \mathrm{a}$ & $244 \mathrm{a}$ \\
\hline Fabric & $4.3 \mathrm{~b}$ & $10 \mathrm{~d}$ & $2 \mathrm{~b}$ & $0 \mathrm{~b}$ & $1 \mathrm{~b}$ & $11 \mathrm{c}$ \\
\hline Mulch & $21 \mathrm{~b}$ & $126 \mathrm{~cd}$ & $90 \mathrm{~b}$ & $5 \mathrm{a}$ & $65 \mathrm{a}$ & $99 \mathrm{~b}$ \\
\hline Barley & $27 \mathrm{a}$ & $338 \mathrm{bc}$ & $1,686 \mathrm{a}$ & $1 \mathrm{~b}$ & $42 \mathrm{a}$ & $138 \mathrm{~b}$ \\
\hline PAM & $173 \mathrm{a}$ & $487 \mathrm{a}$ & $610 \mathrm{a}$ & $3 \mathrm{ab}$ & $52 \mathrm{a}$ & $136 \mathrm{~b}$ \\
\hline
\end{tabular}

Treatment means with the same letter in each column are not significantly different at $P=0.05$. not end up in receiving bodies of water. In a previous study, Mangiafico et al. (2009) showed that concentrations of the harmful insecticide chlorpyrifos in runoff were linearly related to sample turbidity. This suggests that retaining waterborne sediments on-site is an effective method for mitigating runoff of this pesticide. Preventing soil movement with these post row treatments may also reduce the costs of sediment removal from receiving waterways and associated environmental impacts (Tundu et al. 2018).

Phosphorus levels in the first flush of runoff samples were reduced by $24 \%$ to $85 \%$ in all treatments compared with untreated soil at Somis in 2018, except for PAM on Feb. 27, 2018 (fig. 4). Lack of efficacy of PAM on that date may have resulted from deterioration of the PAM seal due to soil disturbance (foot traffic during cane pruning) after PAM application and before runoff sample collection. At Somis in 2016-2017 and Santa Maria in 2018, we observed a similar reduction in phosphorus by all post row treatments compared with untreated soil (data not shown). Since phosphorus is normally adsorbed to soil particles (Zhang et al. 2016), reduction in turbidity and phosphorus in runoff samples from treated post rows followed a similar trend. Reducing losses of phosphorus from production fields may help prevent eutrophication in receiving waterways when this microelement is limiting for algal growth (Correll 1996).

\section{Control of weeds, raspberry shoots}

Since tunnel post rows receive water and retain soil moisture, conditions are favorable for weed growth. At both locations weed barrier fabric provided nearly complete weed control (table 4) with only occasional weed germination in areas where soil was deposited on the top of the fabric. Application of PAM did not provide control, and weed densities in PAM-treated rows were similar to those in untreated plots. Yard waste mulch provided $81 \%$ to $90 \%$ weed control at Somis but did not control weeds in two out of three evaluation dates at Santa Maria (table 4). Mulch at Santa Maria was much finer compared with the one at Somis, and likely decomposed more rapidly, allowing weed growth.

Barley cover crop provided $86 \%$ and $42 \%$ weed control on two evaluation dates at Somis, but after barley was reseeded, high germination of little mallow occurred (Jan. 17, 2018, table 4). Incorporation of barley during reseeding likely disturbed hard-coated weed seeds sufficiently to break dormancy; however, mallow was controlled before seed production when barley was mowed in spring. Barley cover crop 
at Santa Maria provided $87 \%$ and $43 \%$ weed control at two out of three evaluation dates.

At Somis in 2018, we observed 3.5 more volunteer raspberry shoots $(P=0.001)$ in post rows with mulch compared with other treatments or untreated plots (data not shown). Unlike weeds, raspberry shoots were able to penetrate mulch and establish, likely benefiting from the greater soil moisture content under it (table 2).

These results show that weed barrier fabric, mulch and barley (when adequately applied and managed) can effectively reduce weed control costs in raspberry tunnel post rows, but greater volunteer raspberry shoot management may be required if mulch is used.

\section{Costs of post row treatments}

To estimate the costs of the barley cover crop, we obtained machine use and labor hours for seeding, raking and mowing from cost studies for raspberry production (Bolda et al. 2017). Cover crop treatment at 500 pounds per acre costs $\$ 29.42$ for the treatment area minus the weed control benefit of about $\$ 18.60$, resulting in the net cost approximates of $\$ 10.83$ for the treatment, or $\$ 59.55$ per acre per tunnel period (table 5).

The amount of weed block fabric required for the experimental plot area ( 1,800 square feet) was 0.22 roll, priced at $\$ 349.31$ per roll. Ninety

TABLE 5. Sample costs of raspberry tunnel post row treatments based on a study at Somis and Santa Maria

\begin{tabular}{|c|c|c|}
\hline Materials and labor & Costs/tunnel cycle/treatment area* & Costs/tunnel cycle/acre ${ }^{\dagger}$ \\
\hline & $\$$ & $\$$ \\
\hline \multicolumn{3}{|l|}{ Fabric } \\
\hline \multicolumn{2}{|l|}{ Fabric cost (one roll covers $8,071 \mathrm{ft}^{2}$ ) at $\$ 349.31 /$ roll } & 428.47 \\
\hline \multicolumn{2}{|l|}{ Pins ( 90 for treatment area of $1,800 \mathrm{ft}^{2}$ ) at $\$ 0.12 /$ pin } & 59.40 \\
\hline \multicolumn{2}{|l|}{ Labor (two people at 0.5 hour each) at $\$ 15.00 /$ hour } & 82.50 \\
\hline \multicolumn{2}{|l|}{ Total cost for fabric treatment } & 570.37 \\
\hline \multicolumn{3}{|l|}{ Reuse of fabric for another planting: } \\
\hline Unpinning cost (two people at 0.5 hour each ) & 15.00 & 82.50 \\
\hline Pinning back for the planting (two people at 0.5 hour each ) & 15.00 & 82.50 \\
\hline Total cost with fabric reuse (two tunnel cycles) & 133.70 & 735.37 \\
\hline Total cost per tunnel cycle & 66.85 & 367.68 \\
\hline Less weed control cost in post rows at $\$ 300 /$ ac/year ( $100 \%$ weed control) & -37.19 & -204.55 \\
\hline Total fabric treatment cost & 29.66 & 163.14 \\
\hline \multicolumn{3}{|l|}{ Mulch } \\
\hline Mulch cost $\left(90 \mathrm{ft}^{3}\right.$ for $\left.1,800 \mathrm{ft}^{2}\right)$ at $\$ 15 / \mathrm{yd}^{3}\left(\$ 0.56 / \mathrm{ft}^{3}\right): 495 \mathrm{ft}^{3} / \mathrm{ac}$ & 50.00 & 275.00 \\
\hline Delivery and spreading: 0.74 hours at $\$ 15 /$ hour & 11.10 & 61.05 \\
\hline Total cost for mulch treatment & 61.10 & 336.05 \\
\hline Less weed control in post rows at $\$ 300 / a c /$ year ( $70 \%$ weed control) & -26.03 & -143.18 \\
\hline Total mulch treatment cost & 35.07 & 192.87 \\
\hline \multicolumn{3}{|l|}{ Cover crop } \\
\hline \multicolumn{3}{|l|}{ Cover crop planting: } \\
\hline $500 \mathrm{lbs} / \mathrm{ac}\left(43,560 \mathrm{ft}^{2}\right)$ at $\$ 20 / 50 \mathrm{lbs}$ (two times) & 8.26 & 45.45 \\
\hline \multicolumn{3}{|l|}{ Labor hours for light tilling with hand rototiller: } \\
\hline Two people (20 min each) at $\$ 15 /$ hour (two times for two seedings) & 10.00 & 55.00 \\
\hline Mowing (two times): Two people (20 min/each) (two times for two seedings) & 10.00 & 55.00 \\
\hline Machine cost: mowing at \$14/acre (from cost studies) & 0.58 & 3.18 \\
\hline Weedwacker (same as mowing) & 0.58 & 3.18 \\
\hline Less weed control in post rows at $\$ 300 / a c /$ year ( $50 \%$ control) & -18.60 & -102.27 \\
\hline Total cover crop treatment cost & 10.83 & 59.55 \\
\hline \multicolumn{3}{|l|}{ Polyacrylamide (PAM) } \\
\hline PAM cost (application at $2 \mathrm{lbs} / \mathrm{ac}$ at $\$ 4 / \mathrm{lb}$ (six times application) & 1.98 & 10.91 \\
\hline Labor at $250 \mathrm{~min} / \mathrm{ac}$ and wage rate $\$ 15 /$ hour (six times application) & 15.50 & 85.23 \\
\hline Total PAM cost & 17.48 & 96.14 \\
\hline Less weed control cost in the post rows & 0.00 & 0.00 \\
\hline Total PAM treatment cost & 34.96 & 192.27 \\
\hline
\end{tabular}

* The treatment area consists of one post row $\left(1,800 \mathrm{ft}^{2}\right)$; one tunnel cycle $=3$ years.

† One acre $=5.5$ post rows; one tunnel cycle $=3$ years. 
metal pins were used to pin the 1,800-square foot fabric area at a cost of $\$ 0.12$ per pin. The labor needed for spreading and pinning the fabric in the experiment plot was 1 hour (two workers at 0.5 hour each) at \$15 per hour. Assuming the fabric serves two tunnel periods, only half of the cost of the fabric material is applied to one tunnel period. Fabric also provides $100 \%$ weed control in post rows. Therefore, the cost of fabric treatment per tunnel period is $\$ 29.66$ for the treatment area, or $\$ 163$ per acre for one tunnel period.

The volume of applied yard waste mulch should be sufficient to cover the entire post row with a 2- to 3 -inch thick layer. Ninety cubic feet of mulch, priced at $\$ 0.56$ per cubic foot ( $\$ 15$ per cubic yard), was applied to the 1,800 -square foot treatment area. Delivery and spreading on flat ground with a front end loader and spreader costs $\$ 270$ per acre. In cases where smaller equipment is used, it would take more labor - at least a day for two people to spread an acre, as it is a slow process and depends on how well the mulch spreads out in the field. In terms of weed control, mulch controlled $70 \%$ of the weeds in post row areas. Mulch treatment cost is one of the highest at $\$ 35.07$ for the treatment area, or $\$ 192$ per acre per tunnel period.

The PAM product (Soil Binder DC) was applied at 2 pounds per acre ( 0.083 pounds for the 1,800 square feet) and was priced at $\$ 4.00$ per pound. PAM was applied six times per tunnel period; hence, the total PAM cost for this treatment is $\$ 1.98$ for the treatment area. The labor cost for applying PAM was calculated at 250 minutes per acre (10.33 minutes for the 1,800-square foot treatment area) per time at a wage of $\$ 15$ per hour. Therefore, the PAM treatment cost became $\$ 34.96$ per post row, or $\$ 192.27$ per acre.

The costs of the treatments in this study were very low: $0.7 \%$ to $2.4 \%$ of the total cultural costs of raspberry production (Bolda et al. 2017). This suggests that little investment in soil and runoff management can be cost-effective over time for sustainable plasticulture crop production.

\section{Next steps}

During this trial, California was experiencing the drought of 20112019 , and these treatments were used in periods when lower runoff and sediment movement would have been expected. However, we observed similar treatment efficacy during low ( $<0.2$ inches) and high (> 1 inch) rainfall events in these trials, which suggests the treatments were resilient during wet periods. The four treatments in the study all reduced runoff flows and sediment transport (and consequently phosphorus movement) compared with the untreated rows. However, additional work on runoff flow rates and the effect of infiltration on soluble nitrogen forms is needed to more fully quantify the treatment effects with respect to nitrogen balance in these systems.

Our treatment cost analysis serves as a template for tunnel users to assess the feasibility of inputs and costs in their production systems, which may be different from those in this study. During the project we conducted several outreach events for growers and field workers where we displayed the treatments and discussed the in-progress results. At the end of the project, we developed bilingual guidelines for runoff management to facilitate treatment adoptions. These guidelines are available online at https://ucanr.edu/sites/ucceventura/files/304038. pdf (English) and https://ucanr.edu/sites/ucceventura/files/304039. pdf (Spanish). These resources enable tunnel users to select best management practices to protect their fields from soil and nutrient losses and to comply with runoff regulations aimed at protecting the environment. CA

\footnotetext{
O. Daugovish is Strawberry and Vegetable Crops Advisor and B. Faber is Soils and Water, Avocados and Minor Subtropicals Advisor, UC Cooperative Extension (UCCE) Ventura County; E. Takele is Farm Management/Agricultural Economics Area Advisor, UCCE Riverside County; J. Whiteford is District Scientist, Ventura County Resource Conservation District; and L. Wu is Professor of Soil and Water Science and UCCE Water Management Specialist in the Department of Environmental Sciences, UC Riverside. We greatly acknowledge help and contributions from Driscoll/Reiter AC, AGQ lab and funding from the California Department of Food and Agriculture.
}

\section{References}

Bolda M, Tourte L, Murdock J, Sumner D. 2017. Sample Costs to Produce and Harvest Fresh Market Raspberries - Primocane Bearing - Central Coast Region. UC ANR, UC Cooperative Extension, Agricultural Issues Center. $36 \mathrm{p}$.

Corell D. 1996. The role of phosphorus in the eutrophication of receiving waters: A review. J Env Quality 27(2):261-6.
[ILRP] Irrigated Lands Regulatory Program. 2017. Eastern San Joaquin River Watershed Agricultural Order. SWRCB/ OCC Files A-2239(a)-(c). www.waterboards.ca.gov/ public_notices/petitions/ water_quality/a2239 sanjoaquin_ag.shtml

Lu J, Wu L, Faber B. 2008. Erosion control and runoff management. In: Newman J (ed.). Greenhouse and Nursery Management Practices to Protect Water Quality. UC ANR publication 3508. p 83-96.
Mangiafico S, Newman J, Merhaut D, et al. 2009. Nutrients and pesticides in stormwater runoff and soil water in production nurseries and citrus and avocado groves in California. HortTechnology 19(2):360-7. [RCDMC] Resource Conservation District of Monterey County. 2014. Stormwater erosion and runoff on Salinas and Pajaro valley farms. Technical paper. www.rcdmonterey.org/ images/docs/publications/

rcdmc-valley-runoff-anderosion.pdf

SAS Institute. 2007. SAS version

9. Cary, NC.
Tundu C, Tumbare M, Onema IM. 2018. Sedimentation and its impacts/effects on river system and reservoir water quality: case study of Mazowe catchment,

Zimbabwe. Int Assoc Hydrological Sci 377:57-66

Westra S, Fowler HJ, Evans JP, et al. 2014. Future changes to the intensity and fre-

quency of short-duration extreme rainfall. Rev Geophys 52(3). https://agupubs. onlinelibrary.wiley.com/doi/ full/10.1002/2014RG000464
[USDA -NRCS] US Department of Agriculture Natural Resources Conservation Service. 2019. National conservation practice standards. EQIP 2019-1. www. nrcs.usda.gov/wps/portal/ $\mathrm{nrcs} / \mathrm{main} /$ national/programs/ financial/eqip/

Zhang L, Du Y, Du C, et al. 2016. The adsorption/desorption of phosphorus in freshwater sediments from buffer zones: the effects of sediment concentration and $\mathrm{pH}$. Environ Monit Assess 188(1):13. www.ncbi.nlm.nih gov/pubmed/26638155 